\title{
Sistem Pendukung Keputusan Menentukan Matakuliah Pilihan pada Kurikulum Berbasis KKNI Menggunakan Metode Fuzzy Sugeno
}

\author{
Muhammad Dedi Irawan \\ Dosen Teknik Informatika, Universitas Asahan \\ Jl. Jend. Ahmad Yani, Kisaran, Universitas Asahan \\ temansejati.dedi@gmail.com
}

\begin{abstract}
Decision-making is the process of selecting alternative actions to achieve a particular goal or goal. Decision-making determines the course of choice in a curriculum based on a systematic approach to problems through the process of collecting data into information and coupled with factors that need to be considered in decision making. In a decision-making process, decision-makers are often faced with a variety of issues that stem from a variety of criteria. As a practical example, determining the KKNI-based elective course often faces difficulties in determining priorities in decision-making and policy processes for subject selection. So that decision support system can be used by students in the decision making process, combined with Fuzzy Sugeno method within the system, then they can integrate with each other, so as to solve the problem.
\end{abstract}

Keywords: : Fuzzy Sugeno, DSS, Selected Subjects, KKNI Based Curriculum

Intisari-Pengambilan Keputusan merupakan proses pemilihan alternatif tindakan untuk mencapai tujuan atau sasaran tertentu. Pengambilan keputusan menentukan matakuliah pilihan pada kurikulum berbasis kkni dilakukan dengan pendekatan sistematis terhadap permasalahan melalui proses pengumpulan data menjadi informasi serta ditambah dengan faktor-faktor yang perlu dipertimbangkan dalam pengambilan keputusan. Pada suatu proses pengambilan keputusan, para pengambil keputusan seringkali dihadapkan pada berbagai masalah yang bersumber dari beragamnya kriteria. Sebagai contoh praktis, menentukan matakuliah pilihan berbasis KKNI sering menghadapi kesulitan dalam menentukan prioritas dalam proses pengambilan keputusan dan kebijakan terhadap pemilihan matakuliah. Sehingga sistem pendukung keputusan dapat digunakan oleh mahasiswa dalam proses pengambilan keputusan, dipadukan dengan metode Fuzzy Sugeno didalam sistem tersebut, maka keduanya dapat saling berintegrasi, sehingga mampu menyelesaikan masalah tersebut.

Kata kunci : Fuzzy Sugeno, SPK, Matakuliah Pilihan, Kurikulum Berbasis KKNI

\section{PENDAHULUAN}

Perkembangan kerangka kurikulum berbasis KKNI (Kerangka Kualifikasi Nasional Indonesia) khususnya di bidang Teknik Informatika saat ini, sangat menentukan bagi mahasiswa dalam memilih matakuliah. Kurikulum berbasis KKNI merupakan kurikulum yang baru. Sehingga dalam kurikum tersebut terdapat matakuliah pilihan yang memungkinkan mahasiswa lulus sesuai dengan profil lulusan dan berguna bagi stakeholder.

Dari analisis masalah yang telah diuraikan penulis berkesimpulan dalam menentukan matakuliah pilihan perlunya sistem pedukung keputusan bagi mahasiswa dalam menentukan matakuliah pilihan sesuai dengan kemampuan, minat dan bakat.

Berdasarkan hal tersebut penulis mengimplementasikan logika fuzzi metode fuzzi Sugeno yang dapat membantu dalam pengambilan keputusan untuk menentukan matakuliah pilihan.

\section{A. Konsep Dasar Logika Fuzzy}

Teori tentang fuzzy set atau himpunan samar pertama kali dikemukakan oleh Lotfi Zadeh sekitar tahun 1965 pada sebuah makalah yang berjudul 'Fuzzy Set'. Setelah itu, sejak pertengahan 1970-an, para peneliti Jepang berhasil mengaplikasikan teori ini kedalam permasalahan teknis (Suyanto, 2014).

Logika fuzzy adalah peningkatan dari logika boolean yang berhadapan dengan konsep kebenaran sebagian. Saat logika klasik menyatakan segala hal dapat didefinisikan dalam istilah biner 
( 0 atau 1 , hitam atau putih, ya atau tidak), logika fuzzy menggantikan kebenaran boolean dengan tingkat kebenaran. Dengan menggunakan logika fuzzy konsep matematis yang mendasari penalaran fuzzy sangat sederhana dan mudah dimengerti (Rizky Meimaharani, 2014).

Ada beberapa jenis metode fuzzy yaitu, fuzzy inference system yang berisi metode-metode untuk melakukan inferensi fuzzy, antara lain metode Tsukamoto, Mamdani, dan Sugeno. Sedangkan fuzzy clustering berisi metode fuzzy c-means, substractive clustering, dan membentuk FIS dengan fuzzy subtractive clustering. Fuzzy Database berisi basisdata fuzzy dengan model Tahani, dan Umano (Sulistiyo Widodo, 2014).

\section{1) Metode Tsukamoto}

Pada metode Tsukamoto, setiap konsekuen pada aturan yang berbentuk IF-THEN harus direpresentasikan dengan suatu himpunan fuzzy dengan fungsi keanggotaan yang monoton. Sebagai hasilnya, output hasil inferensi dari tiap-tiap aturan diberikan secara tegas (crisp) berdasarkan $\alpha$-predikat (fire strength). Hasil akhirnya diperoleh dengan menggunakan rata-rata terbobot(Chabibi Aulia Rahman Al Hasmy, 2011).

\section{2) Metode Mamdani}

Metode Mamdani sering juga dikenal dengan nama metode Max-Min. Metode ini diperkenalkan oleh Ebrahim Mamdani pada tahun 1975. Untuk mendapatkan output, diperlukan 4 tahan terbobot (Chabibi Aulia Rahman Al Hasmy, 2011):

a. Pembentukan himpunan fuzzy

Pada metode Mamdani, baik variabel input maupun variabel output dibagi menjadi satu atau lebih himpunan fuzzy.

b. Aplikasi fungsi implikasi

Pada metode Mamdani, fungsi implikasi yang digunakan adalah Min.

c. Komposisi aturan

Tidak seperti penalaran monoton, apabila sistem terdiri dari beberapa aturan, maka inferensi diperoleh dari kumpulan dan korelasi antar aturan. Ada 3 metode yang digunakan dalam melakukan inferensi sistem fuzzy, yaitu : Max, Additive dan Probabilistik OR (PROBOR).

d. Penegasan (Defuzzy)

Input dari proses defuzzikasi adalah suatu himpunan fuzzy yang diperoleh dari komposisi aturan-aturan fuzzy, sedangkan output yang dihasilkan merupakan suatu bilangan pada domain himpunan fuzzy tersebut. Sehingga jika diberikan suatu himpunan fuzzy dalam range tertentu, maka harus dapat diambil suatu nilai crisp tertentu sebagai output.

\section{3) Metode Sugeno}

Penalaran dengan metode Sugeno hampir sama dengan penalaran Mamdani, hanya saja output (konsekuen) sistem tidak berupa himpunan fuzzy, melainkan berupa konstanta atau persamaan linear. Metode ini diperkenalkan oleh Takagi Sugeno Kang pada tahun 1985 (Chabibi Aulia Rahman Al Hasmy, 2011).

a. Model Fuzzy Sugeno Orde-Nol

Secara umum bentuk model inferensi fuzzy metode TSK Orde-0 adalah :

IF $\left(\mathrm{x}_{1}\right.$ is $\left.\mathrm{A}_{1}\right)$ o $\left(\mathrm{x}_{2}\right.$ is $\left.\mathrm{A}_{2}\right)$ o $\left(\mathrm{x}_{3}\right.$ is $\left.\mathrm{A}_{3}\right)$ o ... o $\left(\mathrm{x}_{\mathrm{n}}\right.$ is $\left.\mathrm{A}_{\mathrm{n}}\right)$ THEN $\mathrm{z}=\mathrm{k}$

dengan $\mathrm{A}_{1}$ adalah himpunan fuzzy ke-i sebagai antesenden, dan $\mathrm{k}$ adalah suatu konstanta (bersifat crisp) sebagai konsekuen.

b. Model Fuzzy Sugeno Orde-Satu

Secara umum bentuk model inferensi fuzzy metode TSK Orde-1 adalah :

$\operatorname{IF}\left(x_{1}\right.$ is $\left.A_{1}\right)$ o $\left(x_{2}\right.$ is $\left.A_{2}\right)$ o ... o $\left(x_{n}\right.$ is $\left.A_{n}\right)$ THEN $\mathrm{z}=\mathrm{p}_{1} * \mathrm{x}_{1}+\ldots+\mathrm{x}_{\mathrm{n}}+\mathrm{q}$ 
Dengan $\mathrm{A}_{1}$ adalah himpunan fuzzy ke-i sebagai antesenden, dan pi adalah suatu konstanta (tegas) ke-i dan q juga merupakan konstanta dalam konsekuen.

Apabila komposisi aturan menggunakan metode Sugeno, maka deffuzikasi dilakukan dengan cara mencari nilai rata-ratanya(Chabibi Aulia Rahman Al Hasmy, 2011).

$$
z=\sum \frac{\mu i Z i}{\mu i}
$$

\section{Keterangan :}

$$
\begin{array}{ll}
\mathrm{Z} & =\text { output perhitungan logika fuzzy } \\
\mathrm{Zi} & =\mathrm{Z} \text { masing-masing rule } \\
\mu \mathrm{i} & =\text { derajat keanggotaan hasil proses }
\end{array}
$$

\section{B. Sistem Pendukung Keputusan}

Menurut Alter (dalam Kusrini, 2007), Sistem pendukung keputusan merupakan sistem informasi yang menyediakan informasi, pemodelan manipulasi data. Sistem ini digunakan untuk membantu pengambilan keputusan dalam situasi yang semiterstruktur, dimana tak seorang pun tahu secara pasti bagaimana keputusan seharusnya dibuat.

\section{METODE PENELITIAN}

Penelitian ini menggunakan metode Sugeno dalam pelaksanaan awal penelitiannya meliputi pengumpulan data. Penelitian ini disusun sebagai penelitian induktif yakni mencari dan mengumpulkan data yang ada di lapangan dengan tujuan untuk mengetahui data-data matakuliah di lingkungan tempat penelitian. Hal diatas sudah secara umum dilakukan banyak orang dalam meneliti.

\section{A. Mengumpulkan Data}

Kerangka kerja ini dimulai dari mengumpulkan data, yang terdiri dari penelitian perpustakaan (library research), penelitian lapangan (field research), dan penelitian laboratorium (labora- tory research).

\section{B. Mengolah Data}

Setelah mengumpulkan data diatas selesai selanjutnya dilakukan pengolahan data. Hal ini bertujuan untuk melakukan pengelompokan terhadap data tersebut sehingga akan memudahkan penulis di dalam melakukan langkah berikutnya. pengolahan data diperlukan untuk melakukan perhitungan pada logika fuzzy.

\section{Mengembangkan Sistem Menggunakan Matlab R2010a}

Tahap ini membahas tentang perancangan dari model sistem dengan menentukan rancangan input di dalam penentuan pemilihan matakuliah dengan ketentuan sudah ditetapkan berdasarkan data yang ada.

\section{Mengimplementasikan Sistem}

Tahapan berikutnya yang akan dilakukan di dalam penelitian adalah melakukan implementasi dari sistem yang telah dibangun, yaitu dengan sistem pendukung keputusan dan memberikan informasi matakuliah yang tepat dengan menggunakan logika fuzzy metode Sugeno.

\section{E. Menguji Sistem}

Pada tahap pengujian ini dijelaskan tentang bagaimana hasil tahapan proses penentuan matakuliah pilihan. Tahapan proses tersebut adalah mengambil data matakuliah dari program studi. Setelah itu, memasukkan data yang telah diperoleh ke dalam sistem pendukung keputusan untuk menentukan matakuliah pilihan. Sehinga hasil dari sistem pendukung keputusan dapat diterima oleh mahasiswa. Pengujian dilakukan dengan kompleks dan diharapkan dapat diketahui kekurangan-kekurangan dari sistem untuk kemudian diperbaiki sehingga kesalahan dari sistem dapat diminimalisasi atau bahkan dihilangkan. Pengujian sistem ini dilakukan untuk mendapatkan hasil yang akurat. 


\section{HASIL DAN PEMBAHASAN}

\section{A. Penentuan Input dan Output}

Untuk menentukan input dan output dapat diperoleh dari semesta pembicaraan.

1) Menentukan Semesta Pembicaraan

Pada objek yang diteliti diperoleh dari Program Studi Teknik Informatika Fakultas Teknik Una diperoleh pada pengumpulan data.

Tabel 1. Semesta Pembicaraan

\begin{tabular}{|c|c|c|c|}
\hline Variabel & Notasi & $\begin{array}{c}\text { Semesta } \\
\text { Pembicaraan }\end{array}$ & Keterangan \\
\hline Kurikulum & $K$ & {$[0-100]$} & $\begin{array}{c}\text { Jumlah } \\
\text { Matakuliah }\end{array}$ \\
\hline
\end{tabular}

\section{2) Menentukan Input}

Input diperoleh dari kurikulum berbasis KKNI di Program Studi Teknik Informatika. Matakuliah yang dijadikan sembagai input adalah matakuliah dari semester 1 sampai dengan 5, terdiri dari matakuliah prasarat dan yang berhubungan dengan matakuliah yang akan dijadikan sebagai output.

Tabel 2. Penentuan Input

\begin{tabular}{|c|c|c|l|}
\hline Variabel & Notasi & $\begin{array}{c}\text { Semesta } \\
\text { Pembicaraan }\end{array}$ & Keterangan \\
\hline $\begin{array}{c}\text { Algoritma } \\
\text { \& Pemrog. } \\
\text { Terstuktur }\end{array}$ & $A$ & {$[0-100]$} & Jumlah Nilai \\
\hline $\begin{array}{c}\text { Struktur } \\
\text { Data \& } \\
\text { Algoritma }\end{array}$ & $D$ & {$[0-100]$} & Jumlah Nilai \\
\hline $\begin{array}{c}\text { Sistem } \\
\text { Operasi }\end{array}$ & $S$ & {$[0-100]$} & Jumlah Nilai \\
\hline $\begin{array}{c}\text { Kriftografi } \\
\&\end{array}$ & $K$ & {$[0-100]$} & Jumlah Nilai \\
$\begin{array}{c}\text { Keamanan } \\
\text { Informasi }\end{array}$ & $G$ & {$[0-100]$} & Jumlah Nilai \\
\hline $\begin{array}{c}\text { Grafika } \\
\text { Komputer }\end{array}$ & $G$ &
\end{tabular}

\section{3) Menentukan Output}

Untuk menentukan output diperoleh dari masing-masing input.
Tabel 3. Penentuan Output

\begin{tabular}{|c|c|c|c|}
\hline Variabel & Notasi & $\begin{array}{c}\text { Semesta } \\
\text { Pembicaraan }\end{array}$ & Keterangan \\
\hline $\begin{array}{c}\text { Sistem } \\
\text { Cerdas }\end{array}$ & $S C$ & {$[0-100]$} & Jumlah nilai \\
\hline Jaringan & $J$ & {$[0-100]$} & Jumlah nilai \\
\hline Multimedia & $M$ & {$[0-100]$} & Jumlah nilai \\
\hline
\end{tabular}

\section{B. Pembentukan Logika Fuzzy Sugeno}

Setelah ditentukan semesta pembicaraan, maka langkah selanjutnya menentukan aturan fuzzy dengan metode Sugeno. Untuk mendapatkan nilai output dari pendapatan akhir dengan aturan fuzzy Sugeno dilakukan dengan pembentukan himpunan fuzzy dan derajat keanggotaannya (fuzzifikasi), penentuan rules, penalaran (inferensi) dan defuzzifikasi (defuzzification).

\section{1) Fuzzyfikasi}

Fuzzifikasi (fuzzification) merupakan proses memetakan nilai ke dalam himpunan fuzzy dan menentukan derajat keanggotaannya di dalam himpunan fuzzy. Himpunan fuzzy dan derajat keanggotaan (member function) yang digunakan pada tiap variabel fuzzy ditentukan berdasarkan data kurikukum. (Tabel 4).

a. Fungsi Derajat Keanggotaan $(\mu)$ Variabel Input Algoritma \& Pemrog. Terstuktur

$$
\begin{aligned}
& \mu_{C}[\mathrm{~A}]=\left\{\begin{array}{cc}
\frac{(\mathrm{x}-40)}{(55-40)} & ; 40 \leq \mathrm{x} \leq 55 \\
1 & ; \mathrm{x}=55 \\
\frac{(70-\mathrm{x})}{(70-55)} & ; 55 \leq \mathrm{x} \leq 70 \\
0 & ; \mathrm{x} \leq 40 \text { atau } \mathrm{x} \geq 70
\end{array}\right. \\
& \mu_{B}[\mathrm{~A}]=\left\{\begin{array}{cc}
\frac{(\mathrm{x}-55)}{(70-55)} & ; 55 \leq \mathrm{x} \leq 70 \\
1 & ; \mathrm{x}=70 \\
\frac{(85-\mathrm{x})}{(85-70)} & ; 70 \leq \mathrm{x} \leq 85 \\
0 & ; \mathrm{x} \leq 55 \text { atau } \mathrm{x} \geq 85
\end{array}\right. \\
& \mu_{S}[\mathrm{~A}]=\left\{\begin{array}{cc}
\frac{(\mathrm{x}-70)}{(85-70)} & ; 70 \leq \mathrm{x} \leq 85 \\
1 & ; \mathrm{x}=85 \\
\frac{(100-\mathrm{x})}{(100-85)} & ; 85 \leq \mathrm{x} \leq 100 \\
0 & ; \mathrm{x} \leq 70 \text { atau } \mathrm{x} \geq 100
\end{array}\right.
\end{aligned}
$$


Tabel 4. Himpunan Input Fuzzy

\begin{tabular}{|c|c|c|c|c|}
\hline \multicolumn{2}{|l|}{ Variabel } & \multicolumn{2}{|c|}{ Himpunan Input Fuzzy } & \multirow{2}{*}{ Domain } \\
\hline Nama & Notasi & Nama & Notasi & \\
\hline \multirow{3}{*}{ Algoritma \& Pemrog. Terstuktur } & \multirow{3}{*}{$A$} & Cukup & $C$ & {$[40-70]$} \\
\hline & & Baik & $B$ & {$[55-85]$} \\
\hline & & Sangat Baik & $S$ & {$[70-100]$} \\
\hline \multirow{3}{*}{ Struktur Data \& Algoritma } & \multirow{3}{*}{$D$} & Cukup & $C$ & {$[40-70]$} \\
\hline & & Baik & $B$ & {$[55-85]$} \\
\hline & & Sangat Baik & $S$ & {$[70-100]$} \\
\hline \multirow{3}{*}{ Sistem Operasi } & \multirow{3}{*}{$S$} & Cukup & $C$ & {$[40-70]$} \\
\hline & & Baik & $B$ & {$[55-85]$} \\
\hline & & Sangat Baik & $S$ & {$[70-100]$} \\
\hline \multirow{3}{*}{ Kriftografi \& Keamanan Informasi } & \multirow{3}{*}{ K } & Cukup & $C$ & {$[40-70]$} \\
\hline & & Baik & $B$ & {$[55-85]$} \\
\hline & & Sangat Baik & $S$ & {$[70-100]$} \\
\hline \multirow{3}{*}{ Grafika Komputer } & \multirow{3}{*}{$G$} & Cukup & $C$ & {$[40-70]$} \\
\hline & & Baik & $B$ & {$[55-85]$} \\
\hline & & Sangat Baik & $S$ & {$[70-100]$} \\
\hline
\end{tabular}

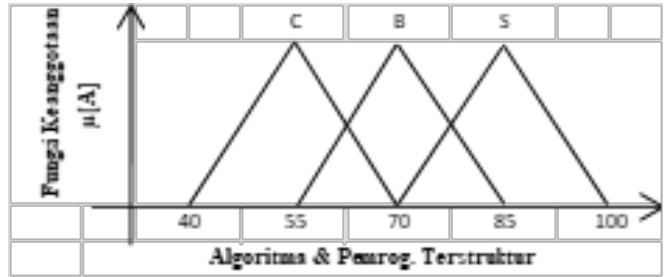

Gambar 1. Representasi Fungsi Derajat Keanggotaan $(\mu)$ Variabel Input Algoritma \& Pemrog. Terstruktur

b. Fungsi Derajat Keanggotaan $(\mu)$ Variabel Input Struktur Data \& Algoritma

$$
\begin{aligned}
& \mu_{C}[D]=\left\{\begin{array}{cc}
\frac{(x-40)}{(55-40)} & ; 40 \leq x \leq 55 \\
1 & ; x=55 \\
\frac{(70-x)}{(70-55)} & ; x \leq 40 \text { atau } x \geq 70
\end{array}\right. \\
& \mu_{B}[D]=\left\{\begin{array}{cc}
\frac{(x-55)}{(70-55)} & ; 55 \leq x \leq 70 \\
1 & ; 70 \leq x \leq 85 \\
\frac{(85-x)}{(85-70)} & ; x \leq 55 \text { atau } x \geq 85
\end{array}\right. \\
& \mu_{S}[\mathrm{D}]=\left\{\begin{array}{cc}
\frac{(\mathrm{x}-70)}{(85-70)} & ; 70 \leq \mathrm{x} \leq 85 \\
1 & ; \mathrm{x}=85 \\
\frac{(100-\mathrm{x})}{(100-85)} & ; \mathrm{x} \leq 70 \text { atau } \mathrm{x} \geq 100
\end{array}\right.
\end{aligned}
$$

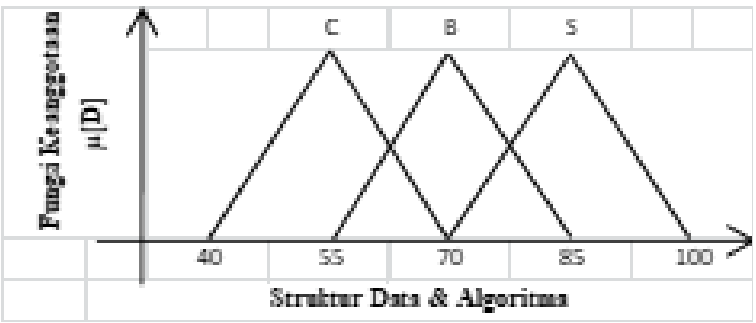

Gambar 2. Representasi Fungsi Derajat Keanggotaan $(\mu)$ Variabel Input Struktur Data \& Algoritma

c. Fungsi Derajat Keanggotaan $(\mu)$ Variabel Input Sistem Operasi

$$
\begin{aligned}
& \mu_{C}[S]=\left\{\begin{array}{cc}
\frac{(x-40)}{(55-40)} & ; 40 \leq x \leq 55 \\
1 & ; x=55 \\
\frac{(70-x)}{(70-55)} & ; 55 \leq x \leq 70 \\
0 & ; x \leq 40 \text { atau } x \geq 70
\end{array}\right. \\
& \mu_{B}[S]=\left\{\begin{array}{cc}
\frac{(\mathrm{x}-55)}{(70-55)} & ; 55 \leq \mathrm{x} \leq 70 \\
1 & ; \mathrm{x}=70 \\
\frac{(85-\mathrm{x})}{(85-70)} & ; 70 \leq \mathrm{x} \leq 85 \\
0 & ; \mathrm{x} \leq 55 \text { atau } \mathrm{x} \geq 85
\end{array}\right. \\
& \mu_{S}[S]=\left\{\begin{array}{cc}
\frac{(\mathrm{x}-70)}{(85-70)} & ; 70 \leq \mathrm{x} \leq 85 \\
1 & ; \mathrm{x}=85 \\
\frac{(100-\mathrm{x})}{(100-85)} & ; 85 \leq \mathrm{x} \leq 100 \\
0 & ; \mathrm{x} \leq 70 \text { atau } \mathrm{x} \geq 100
\end{array}\right.
\end{aligned}
$$




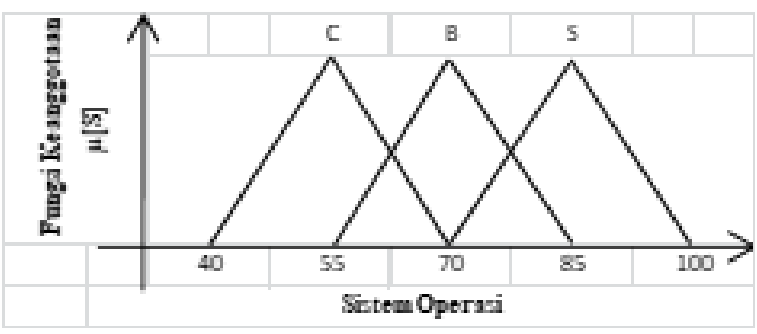

Gambar 3. Representasi Fungsi Derajat Keanggotaan $(\mu)$ Variabel Input Sistem Operasi

d. Fungsi Derajat Keanggotaan ( $\mu$ ) Variabel Input Kriftografi \& Keamanan Informasi

$\mu_{C}[\mathrm{~K}]=\left\{\begin{array}{cc}\frac{(\mathrm{x}-40)}{(55-40)} & ; 40 \leq \mathrm{x} \leq 55 \\ 1 & ; \mathrm{x}=55 \\ \frac{(70-\mathrm{x})}{(70-55)} & ; 55 \leq \mathrm{x} \leq 70 \\ 0 & ; \mathrm{x} \leq 40 \text { atau } \mathrm{x} \geq 70\end{array}\right.$

$\mu_{B}[K]=\left\{\begin{array}{cc}\frac{(x-55)}{(70-55)} & ; 55 \leq x \leq 70 \\ 1 & ; x=70 \\ \frac{(85-x)}{(85-70)} & ; 70 \leq x \leq 85 \\ 0 & x \leq 55 \text { atau } x \geq 85\end{array}\right.$

$\mu_{S}[\mathrm{~K}]=\left\{\begin{array}{cc}\frac{(\mathrm{x}-70)}{(85-70)} & ; 70 \leq \mathrm{x} \leq 85 \\ 1 & ; \mathrm{x}=85 \\ \frac{(100-\mathrm{x})}{(100-85)} & ; 85 \leq \mathrm{x} \leq 100 \\ 0 & ; \mathrm{x} \leq 70 \text { atau } \mathrm{x} \geq 100\end{array}\right.$

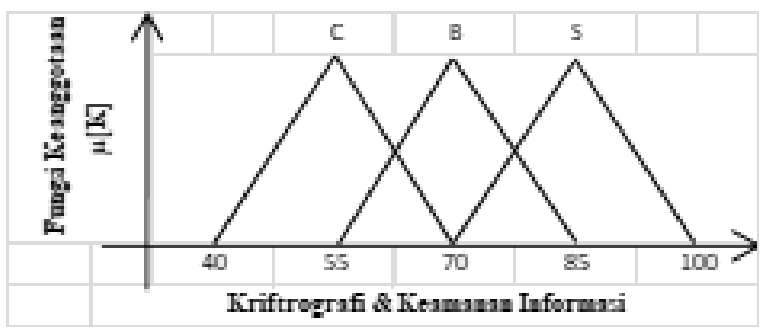

Gambar 4. Representasi Fungsi Derajat Keanggotaan $(\mu)$ Variabel Input Kriptografi \& Keamanan Infromasi

e. Fungsi Derajat Keanggotaan $(\mu)$ Variabel Input Grafika Komputer

$$
\begin{gathered}
\mu_{C}[G]=\left\{\begin{array}{cc}
\frac{(x-40)}{(55-40)} & ; 40 \leq x \leq 55 \\
1 & ; x=55 \\
\frac{(70-x)}{(70-55)} & ; 55 \leq x \leq 70 \\
0 & ; x \leq 40 \text { atau } x \geq 70
\end{array}\right. \\
\mu_{B}[G]=\left\{\begin{array}{cc}
\frac{(x-55)}{(70-55)} & ; 55 \leq x \leq 70 \\
\frac{(85-x)}{(85-70)} & ; x=70 \leq x \leq 85 \\
0 & ; x \leq 55 \text { atau } x \geq 85
\end{array}\right.
\end{gathered}
$$$$
\mu_{S}[\mathrm{G}]=\left\{\begin{array}{cc}
\frac{(\mathrm{x}-70)}{(85-70)} & ; 70 \leq \mathrm{x} \leq 85 \\
1 & ; \mathrm{x}=85 \\
\frac{(100-\mathrm{x})}{(100-85)} & ; 85 \leq \mathrm{x} \leq 100 \\
0 & ; \mathrm{x} \leq 70 \text { atau } \mathrm{x} \geq 100
\end{array}\right.
$$

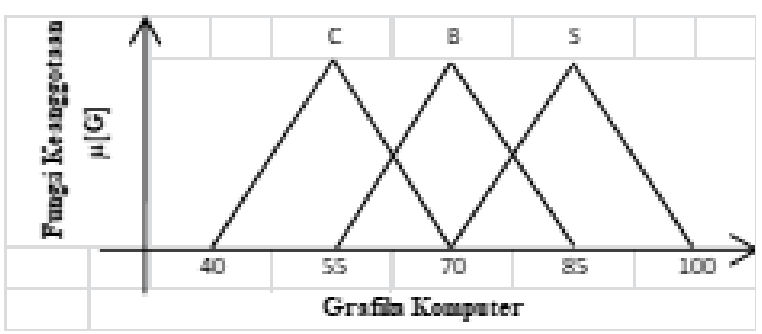

Gambar 5 Representasi Fungsi Derajat Keanggotaan $(\mu)$ Variabel Input Grafika Komputer

Tabel 5. Output Fuzzy

\begin{tabular}{|c|r|l|r|}
\hline \multicolumn{2}{|c|}{ Variabel } & $\begin{array}{l}\text { Himpunan } \\
\text { Input Fuzzy }\end{array}$ & Domain \\
\hline Nama & Notasi & \multicolumn{1}{c|}{ Nama } & Konstanta \\
\hline \multirow{2}{*}{$\begin{array}{c}\text { Sistem } \\
\text { Cerdas }\end{array}$} & \multirow{3}{*}{$S C$} & Cukup & 0 \\
\cline { 3 - 4 } & & Baik & 0.5 \\
\cline { 3 - 4 } Jaringan & \multirow{3}{*}{$J$} & Sangat Baik & 1 \\
\cline { 3 - 4 } & & Cukup & 0 \\
\cline { 3 - 4 } & & Saik & 0.5 \\
\hline \multirow{3}{*}{ Multimedia } & \multirow{2}{*}{$M$} & Cukup & 1 \\
\cline { 3 - 4 } & & Baik & 0.5 \\
\cline { 3 - 4 } & & Sangat Baik & 1 \\
\hline
\end{tabular}


a. Fungsi Derajat Keanggotaan $(\mu)$ Variabel Output Sistem Cerdas

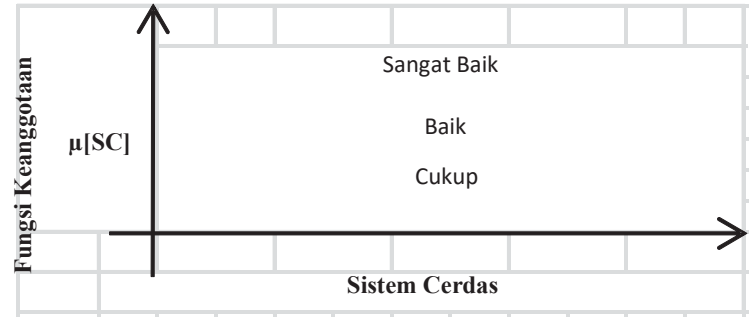

Gambar 6. Representasi Fungsi Derajat Keanggotaan $(\mu)$ Variabel Output Sistem Cerdas

b. Fungsi Derajat Keanggotaan $(\mu)$ Variabel Output Jaringan

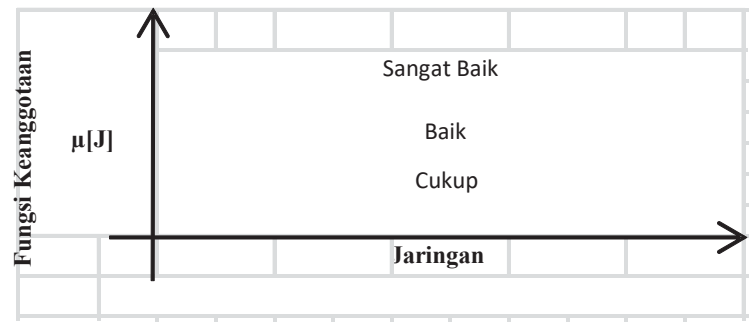

Gambar 7. Representasi Fungsi Derajat Keanggotaan $(\mu)$ Variabel Output Jaringan

c. Fungsi Derajat Keanggotaan $(\mu)$ Variabel Output Multimedia

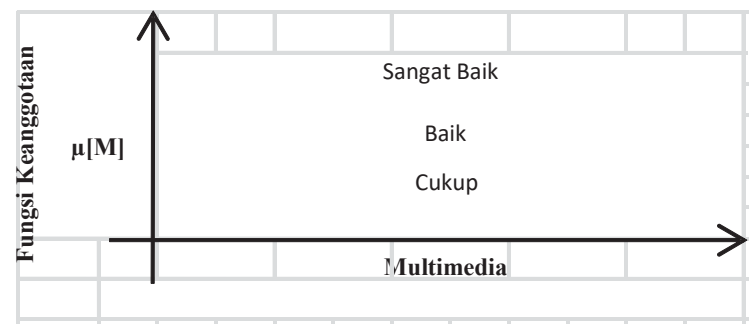

Gambar 8. Representasi Fungsi Derajat Keanggotaan $(\mu)$ Variabel Output Multimedia

\section{2) Pembentukan Rules}

Rules berupa pernyataan kualitatif yang ditulis dalam bentuk IF-THEN, sehingga mudah dimengerti. Rules pada Fuzzy Inference System (FIS) dalam memanajeman bandwidth internet didasari pada jumlah inputan dan jumlah himpunan fuzzy. Penentuan rules didasarkan pada pengujian secara manual dengan memperhitungkan probabilitas kemungkinan yang terjadi dengan kombinasi variabel. Rules yang terbentuk adalah 81 rule.

\section{3) Penentuan Mesin Inferensi}

Penentuan mesin inferesi yang digunakan adalah funggsi MIN (nilai terendah) dari rule-rule yang diperoleh.

\section{4) Defuzzifikasi}

Defuzzifikasi yang digunakan adalah metode weighted avarege (nilai rata-rata)

\section{Pengujian Perhitungan Aplikasi Matlab}

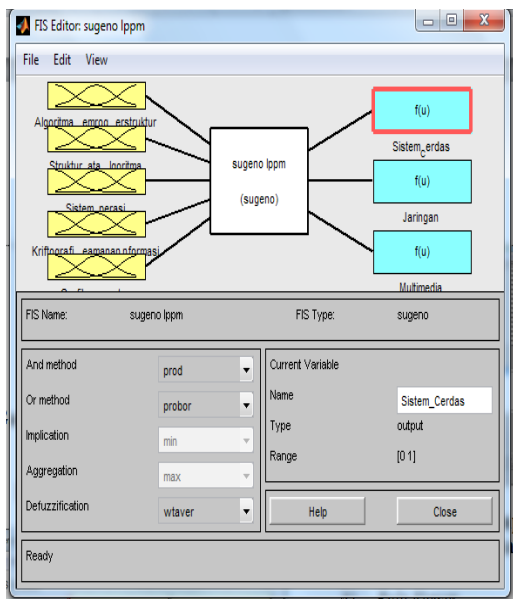

Gambar 9. Tampilan Jendela Setting Parameter Input dan Output

1) Fungsi keanggotaan untuk variabel input

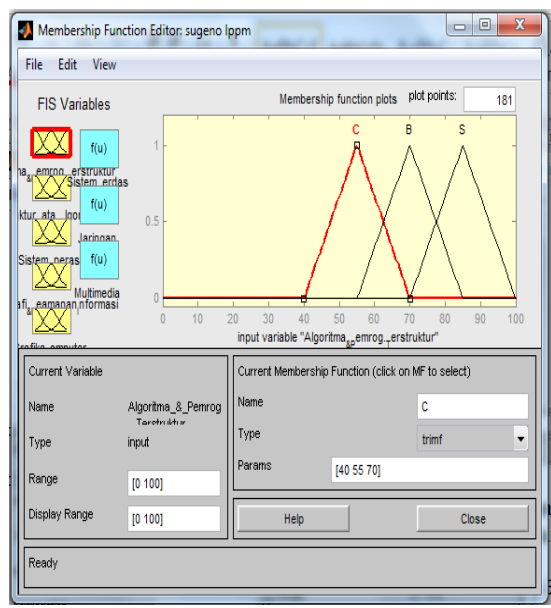

Gambar 10. Tampilan Jendela Fungsi Keanggotaan Variabel Input 
2) Fungsi keanggotaan untuk variabel output

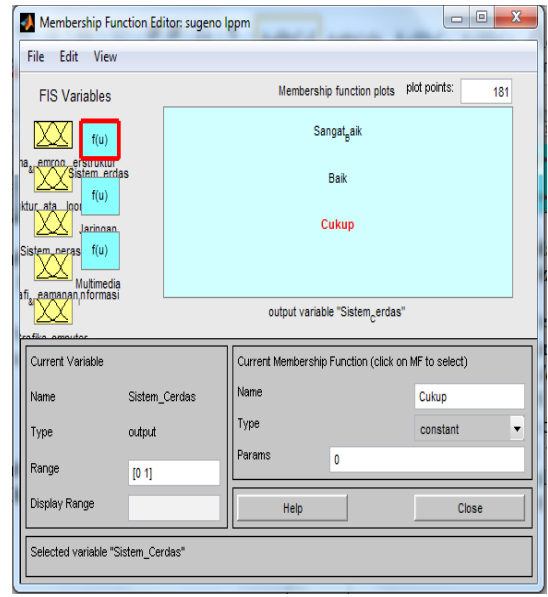

Gambar 11.Tampilan Jendela Fungsi Keanggotaan Variabel Output

3) Pembentukan Rules

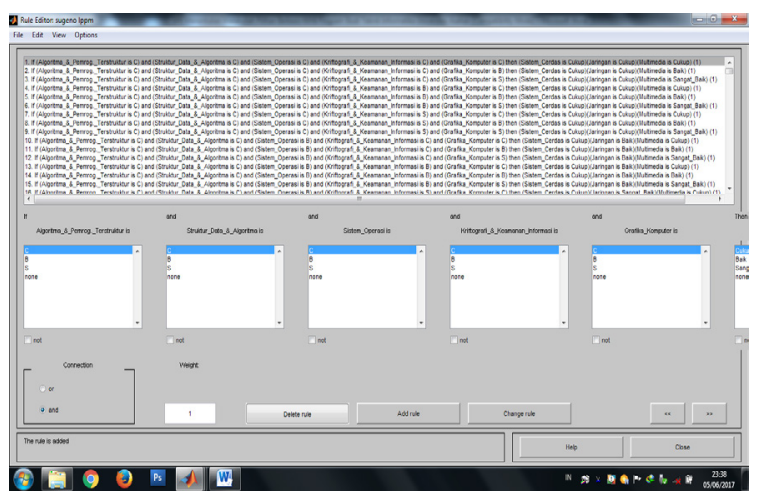

Gambar 12. Tampilan Jendela Pembentukan Rule

4) Rule Viewer

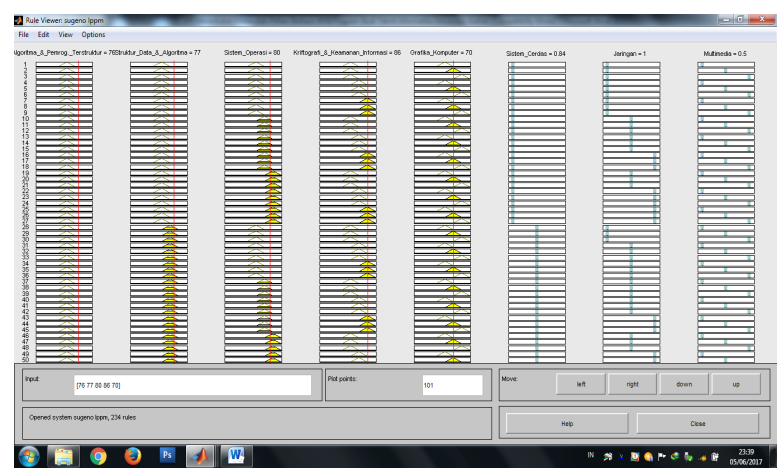

Gambar 13. Tampilan Jendela Rule Keseluruhan

Dari pengujian diinputkan nilai untuk masingmasing matakuliah prasyarat sebagai contoh yaitu : a. Nilai Algoritma \& Pemrog. Terstruktur $=80$

b. Struktur Data \& Algoritma $\quad=65$

c. Sistem Operasi $=75$

d. Kriftografi \& Keamanan Informasi $=80$

e. Grafika Komputer $=75$

Mendapatkan Hasil dari Setiap Matakuliah
a. Sistem Cerdas $=0,722$
b. Jaringan $=0,889$
c. Multimedia $=0,667$

Dari Hasil tersebut terdapat bahwa nilai Matakuliah Jaringan Lebih tinggi dengan nilai 0,889 atau sama dengan baik.

\section{KESIMPULAN}

Berdasarkan penelitian, implementasi dan pengujian, maka dapat diambil kesimpulan sebagai berikut:

Hasil perhitungan aplikasi matlab menunjukkan nilai yang sesuai dengan kaidah fuzzy Sugeno. Sehingga bisa disimpulkan bahwa metode fuzzy Sugeno dapat dimanfaatkan untuk menentukan matakuliah pilihan pada kurikulum berbasis KKNI Program Studi Teknik Informatika Fakultas Teknik Universitas Asahan.

\section{DAFTAR PUSTAKA}

CHABIBI AULIA RAHMAN AL HASMY, F. A., SETIAWARDHANA 2011. Penentuan Peran Dalam Robot Sepak Bola Dengan Metode Fuzzy Sugeno. Jurnal Eepis Final Project, 1-7.

Kusrini 2007. Pengenalan Sistem Informasi. Penerbit Andi. Yogyakarta

RIZKY MEIMAHARANI, T. L. 2014. Analisis Sistem Inference Fuzzy Sugeno Dalam Me- 
nentukan Harga Penjualan Tanah Untuk Pembangunan Minimarket. Jurnal SIMETRIS, Vol. 5 No.1, 1-8.

SULISTIYO WIDODO dan VICTOR G UTOMO (2014). Rancang Bangun Aplikasi Recommender Berbasis WAP Menggunakan Metode Fuzzy Model Tahani. Jurnal Teknologi Informasi Dan Komunikasi, Vol. 5, 25-34.

SUYANTO. 2014. Artificial Intelegence Searching, Reasoning, Planing dan Learning. Bandung : Informatika. 